$\frac{}{\text { 究 }}$

\title{
陰イオン交換膜を用いた硫酸第一鉄水溶液の 電解における溶液条件の効率におよぼす影響
}

\author{
近藤 嘉 一**小池一幸* \\ Effects of Electrolyte Conditions on Efficiencies in \\ Electrolysis of Ferrous Sulfate \\ Studies on Iron Electrodeposition from Sulfate Bath by Using \\ Anion Exchange Membrane (Part 1) \\ Yoshikazu KONDO and Kazuyuki KOIKE
}

\begin{abstract}
This paper describes the iron electrodeposition from a solution mainly composed of ferrous sulfate catholyte by using two compartment cells separated by an anion exchange membrane. In particular, it describes the effects of electrolyte conditions on current efficiencies for iron deposition on cathode and on efficiency of sulfuric acid generation in anolyte. There were close relations among the concentration of sulfuric acid in anolyte, $\mathrm{pH}$ of catholyte, efficiency of sulfuric acid generation, and efficiency of iron deposition. When the sulfuric acid concentration in the anolyte increased, the efficiency of sulfuric acid (generated in the anolyte passing through the anion exchange membrane from the catholyte) decreased, which led to lowering of the $\mathrm{pH}$ value of catholyte and also lowering of the iron deposition efficiency on the cathode. The current efficiency for iron deposition rapidly decreased when the $\mathrm{pH}$ value of ferrous sulfate catholyte was below 2.5. It was proposed to keep the sulfuric acid concentration in the anolyte at lower than $50 \mathrm{~g} / l$ and to keep the $\mathrm{pH}$ value of catholyte at above 2.5 for the purpose of keeping the efficiency of sulfuric acid (generated in anolyte) higher and of keeping the efficiency of iron deposition (on cathode) higher.
\end{abstract}

\section{1. 緒 言}

現在, 日本において工業的に行なわれている鉄の電解 は, 電解液として, 硫酸第一鉄水溶液または塩化第一鉄 水溶液にアルカリ金属塩やアルカリ土類金属塩などを加 劣浴を用いて，電解鉄片または電解鉄粉を得る方法で ある。この場合，いずれる陽極として電解すべき銑鉄や 鋼を使用する電解精製法である。陽極として鉄を使用す るこれらの方法では, 硫酸第一鉄水溶液などの電解液 は，陽極の鉄を溶解して陰極上に析出させる媒体として

†陰イオン交換膜を用いた硫酸塩浴からの鉄電着に関 する研究 (第 1 報)

* 東洋製缶・東洋鋼鈑綜合研究所（神奈川県横浜市保 土ケ谷区岡沢町22-4)

The Composite Research and Development Center of Toyo Seikan and Toyo Kohan Compania.
の作用しかない。他方, 不溶性陽極を使用し電解液中の 鉄を電解鉄として採取する方法については，ピロータイ トを塩酸抽出した液について, 石綿隔膜を用い, グラフ アイト陽極を使用した電解 ${ }^{1)}$ やイルメナイトから抽出 された塩化鉄溶液にクエン酸または酒石酸を加え, 隔膜 を使用して電解し純鉄を得る特許 ${ }^{2)}$ がみられる。

冷間圧延によって鋼板を製造する工場をはじめとし て，鉄鋼工場においては，鉄鋼表面のスケールまたは酸 化鉄層を除去するために硫酸酸洗イが行なわれる。この 硫酸酸洗廃液中には多量の硫酸第一鉄塩を含んでおり, 中和法や真空加熱蒸発法などによって濃縮後に母液と分 離されて, 高純度の硫酸第一鉄 7 水塩結晶が多量に生産 される。

また,イルメナイトなどのチタン鉱石から酸化チタン 顔料を製造するさいにも，比較的低純度の硫酸第一鉄 7 水塩結晶が多量に副生される。 
本研究は低炭素冷延鋼板の酸洗イによって多量に副生 される高純度の硫酸第一鉄 7 水塩結晶中の鉄の回収を目 的とし, 硫酸第一鉄 7 水塩結晶を水に溶解して水溶液と し，不溶性陽極を用い，陰イオン交換膜を使用した電解 による鉄の電着に関するものである。

陰イオン交換膜を使用しないで，不溶性陽極を用いた 硫酸第一鉄水溶液の電解結果についての詳細は省略する が，鉄は電気化学的に卑な金属であり，また鉄面上での 水素過電圧が小さいために，電解によって生ずる遊離硫 酸によって交換膜を使用しない場合は，水素ガスの発生 のみを生じて鉄の析出が起こらなくなる。したがって， 電解中に硫酸第一鉄水溶液中に生成する遊離硫酸を分離 しなければ，鉄の電析を行なわせることが不可能である といえる。

イオン交換膜の物性については，いくつかの文献 ${ }^{3) ~ 7) ~}$ があり，またイオン交換膜の電気化学的研究について は, 石橋, 清山, 坂井 ${ }^{8)}$,9) らの一連の研究によりくわし く調べられている。イオン交換膜を使用した水溶液電解 の例としては，海水の濃縮と純水の製造をはじめとし， 脱塩 $\left.{ }^{5)}, 6\right)$ や廃酸の再生の研究例 ${ }^{10), 11)}$ がある。

本報に拈いては, 陰イオン交換膜によって分離した電 解槽を用い，硫酸第一鉄 7 水塩結晶を溶解した水溶液を 陰極電解液とし，不溶性鉛陽極を使用し，電解によって 陽極室に硫酸を移行生成させ，陰極での鉄析出効率およ び陽極室に括ける硫酸生成効率におよぼす電解液条件の 影響を明らかにし，これらの間の関係について検討し た。

\section{2. 実験方法}

電解槽はアクリル樹脂製で, 陰イオン交換膜により陰 極室と陽極室に分離した。概略図を図 1 に示す。電解 中, 液の蒸発を防ぐためにアクリル製のフタを取りつけ てある。陰極室と陽極室は, 所定の開口部に陰イオン交 換膜をはさんだ後に両端からステンレスワクで締め付 け, 電解槽全体を恒温水槽中に浸セキして, 所定の温度に

表 1 陰イオン交換膜の性能

\begin{tabular}{|c|c|c|c|}
\hline 名 称 & スクリオン $\mathrm{A}-100$ & $\begin{array}{r}\text { ネオセプター } \\
\text { A F-4T }\end{array}$ & 備 \\
\hline 製 造 会社名 & オルガノ商会 & 德山ソーダ & \\
\hline 湿潤 厚 $+\mathrm{mm}$ & $0.10 \sim 0.12$ & $0.15 \sim 0.20$ & \\
\hline 交換 基の 種 類 & 強 塩 基 性 & 強 塩 基 性 & \\
\hline 電気抵抗 $\Omega / \mathrm{cm}^{2}$ & $4-6$ & $1.8 \sim 2.5$ & $0.5 \mathrm{~N} \mathrm{NaCl}$ 中, $25^{\circ} \mathrm{C}$ \\
\hline 輸 & $0.9<$ & $0.98<$ & $25^{\circ} \mathrm{C} \mathrm{NaCl}$ 水中 \\
\hline 含水量 $\mathrm{gH}_{2} \mathrm{O} / \mathrm{gr}$ 膜 & - & $0.25 \sim 0.35$ & \\
\hline
\end{tabular}

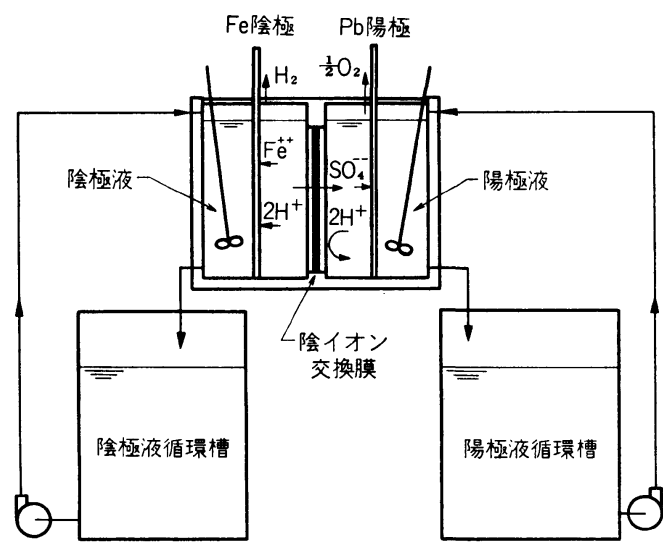

図 12 室 電 解 槽

保持するようにした。陽極は鉛板, 陰極は軟鋼板,ステン レス板を使用した。電極の面積は $50 \times 53 \mathrm{~mm}$ である。陰 極室に硫酸第一鉄水溶液を入れる。陽極室には, 硫酸の 分離回収を目的とするので，硫酸の各種濃度の液を入 れ，アンモニア水で $\mathrm{pH}$ を調整した液を一部用いた。溶 液量は両室とも800cc を標準とした。また, 実験の一部 では陰極液および陽極液を循環することも行なった。こ の場合には，図に示すようにそれぞれの循環槽を設け， ポンプによる液の循環を行なった。液循環の場合は, 温 度の調整は各循環槽中のヒーターによって行なった。液 の循環を行なわない場合, 溶液のカクハンは, 窒素ガス 吹込みまたはインペラによって行なった。

電極反応の基礎式は下記に示す。

陰極反応 $; \mathrm{Fe}^{++}+2 \mathrm{e}^{-} \rightarrow \mathrm{Fe}, 2 \mathrm{H}^{+}+2 \mathrm{e}^{-} \rightarrow \mathrm{H}_{2}$

陽極反応; $\mathrm{SO}_{4}^{--}+\mathrm{H}_{2} \mathrm{O} \longrightarrow \mathrm{H}_{2} \mathrm{SO}_{4}+\frac{1}{2} \mathrm{O}_{2}+2 \mathrm{e}^{-}$

これらの反応は陰イオン交換膜を使用しないで不溶性 陽極を用いた直接電解の場合と同じであるが，鉄イオン が陽極で発生する酸素による酸化を受けないことが特改 としてあげられる。陰極液中の $\mathrm{SO}_{4}^{--}$は電解により陰 イオン交換膜を通って陽極室へ移行する。他方，陽極液 中の水素イオンは陰イオン交換膜のために陰極室へ移動 することができず，この結果， 陰極室硫酸第一鉄水溶液中の硫 酸イオンは陽極室に電解透析し て分離される。陽極室への硫酸 の分離生成は，使用する陰イオ ン交換膜の性能に影響される が，近年イオン交換膜の性能も かなり向上している。本研究の ために，数種類の交換膜につい て比較実験を行ない，その結 果, 表 1 に示す陰イオン交換膜 を使用した。使用した硫酸第一 

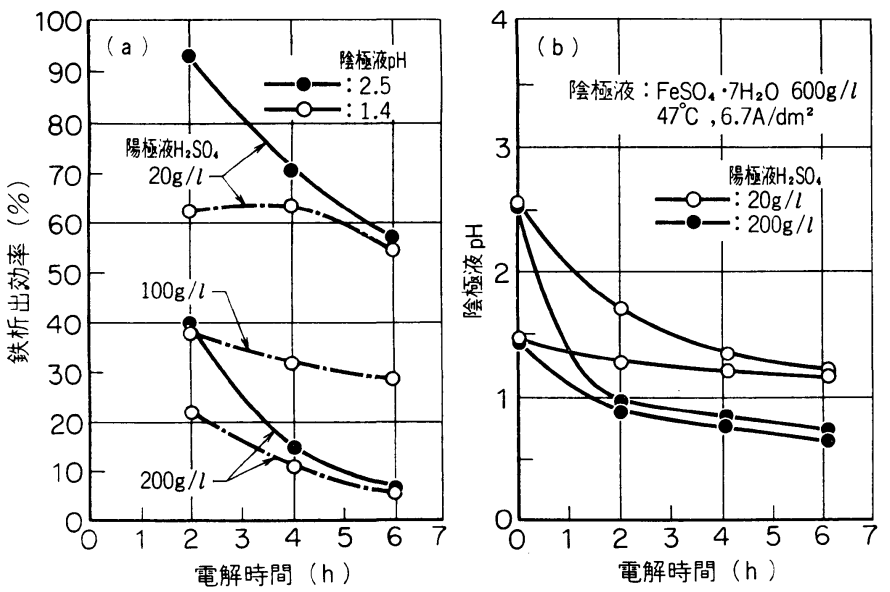

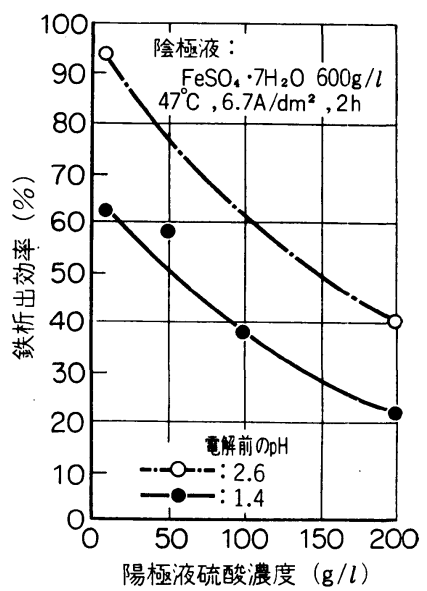

図 2 電解時間と鉄析出効率および陰極液 $\mathrm{pH}$ の变化

図 3 陽極液硫酸濃度と鉄析出効率の関係

鉄 7 水塩は市販 1 級試薬および鉄鋼の硫酸酸洗廃液から 工業的に生産されたもの（東洋鋼鈑製）である。

\section{3. 実験 結 果}

\section{3-1 電解時間による鉄析出効率および陰極液 $\mathrm{pH}$ の 変化}

陰イオン交換膜（スクリオンA 100）を使用した電解 で，陰極液硫酸第一鉄の $\mathrm{pH}$ が2.5と1.4の電解液につい $\tau$, 陽極液硫酸濃度を $20,100,200 \mathrm{~g} / l$ とした場合の電 解時間と鉄析出効率の関係を図 2 (a)に示した。

陰極液 $\mathrm{pH}$ が 2.5 で陽極液硫酸濃度が $20 \mathrm{~g} / \mathrm{l}$ の場合, 電 解 $2 \mathrm{~h}$ 後の鉄析出効率は94\%であるが電解時間の経過と ともに鉄析出効率は低下し $6 \mathrm{~h}$ 後では $58 \%$ に低下する。 陰極液 $\mathrm{pH}$ が 1.4 で陽極液硫酸濃度が $20 \mathrm{~g} / l$ の場合, 電解 $2 \mathrm{~h}$ 後と $4 \mathrm{~h}$ 後では鉄析出効率は62〜 64\%でほぼ等しい が， $6 \mathrm{~h}$ 後には55\%程度に低下寸る。陽極液硫酸濃度が 高い場合には電解 $2 \mathrm{~h} \sim 6 \mathrm{~h}$ の間の鉄析出効率は $40 \%$ 以 下に低下し, 電解時間の経過とともに鉄析出効率はさら に低下してゆく。陽極液硫酸濃度の高低にかかわらず, 電解継続とともに鉄析出効率は低下することがいえる。 この原因として, 陰極液 $\mathrm{pH}$ の変化が考えられる。電解 時間の経過と陰極液 $\mathrm{pH}$ の変化の関係を図示すると図 2 (b)のようになる。陰極液 $\mathrm{pH}$ が 2.5 で陽極液硫酸濃度が $20 \mathrm{~g} / \mathrm{l}$ の場合, 電解 $2 \mathrm{~h}$ 後の $\mathrm{pH}$ は約 1.7 飞低下し, $6 \mathrm{~h}$ 後では約1.3に低下する。陰極液 $\mathrm{pH}$ が1.4で陽極液硫酸 濃度が $20 \mathrm{~g} / l$ の場合電解 $2 \mathrm{~h}$ 後で $\mathrm{pH} 1.3,6 \mathrm{~h}$ 後で約 1.2 程度に低下する。陽極液硫酸濃度が $200 \mathrm{~g} / l$ と高い場 合は電解 $2 \mathrm{~h} \sim 6 \mathrm{~h}$ の間の陰極液 $\mathrm{pH}$ の低下は図に示す ようにいっそう大きく, 電解時間の経過とともに陰極液 $\mathrm{pH}$ は徐々に低下してゆく。

上記のように，電解時間の経過とともに鉄析出効率は 低下し，これは電解時間の経過にともなら陰極液 $\mathrm{pH}$ の
低下と対応しており，から陽極液硫酸濃度の影響をらけ ていることがわかる。

\section{3一2 鉄析出効率および陰極液 pH におよぼす陽極液 硫酸濃度の影響}

鉄の電解と同時に硫酸回収を考慮する場合には，陽極 室に生成する硫酸の濃度を高くすることが望ましい。し かしながら，陽極液硫酸濃度を変化させると陰極に析出 する鉄効率が著しい影響をらけることがすでに示した図 2 からも伺える。そこで電解時間を $2 \mathrm{~h}$ とした場合の鉄 析出効率におよぼす陽極室硫酸濃度の影響を調べた結果 を図 3 に示した。

陰極液 $\mathrm{pH}$ が 2.6 の溶液について, 陽極液硫酸濃度を $10 \mathrm{~g} / l$ とした場合に，鉄析出効率は約 $94 \%$ と高いが，陽 極液硫酸濃度を $200 \mathrm{~g} / l$ とした場合には，鉄析出効率は わずかに $40 \%$ にすぎない。陰極液 $\mathrm{pH}$ が 1.4 の場合には 陽極液硫酸濃度 $10 \mathrm{~g} / l$ で鉄析出効率 $63 \% ， 200 \mathrm{~g} / l$ で $22 \%$ の効率である。このように陽極液硫酸濃度が $10 \mathrm{~g} / l$ の場 合之 $100 \mathrm{~g} / \mathrm{l}$ の場合では, 鉄析出効率の差は約25 35\%, $200 \mathrm{~g} / l$ の場合では40～55\%にもおよぶ。

つぎに陽極液硫酸濃度と陰極液 $\mathrm{pH}$ の関係を図 4 亿示 した。電解前の院極液 $\mathrm{pH}$ が 1.4 で電解 $2 \mathrm{~h}$ 後の $\mathrm{pH}$ の 変化を示す。四からわかるように，陽極室硫酸濃度が高 い注ぞ，電解後の陰極室硫酸第一鉄溶液の $\mathrm{pH}$ 值の低下 が著しく, 陽極液硫酸濃度が $10 \mathrm{~g} / l$ の場合には $2 \mathrm{~h}$ 電解 後の陰極液 $\mathrm{pH}$ は約 1.3 であるが, 硫酸濃度が $100 \mathrm{~g} / l$ で は pH1. 15，200g/l では $\mathrm{pH} 0.85$ 程度まで低下する。

以上に述べた結果から，陽極液硫酸濃度が高いほど陰 イオン交換膜を通して陰極液から陽極液へ電解透析する 硫酸イオン量が減少するものと推定され, その結果, 電 解継続とともに陰極液硫酸第一鉄中の遊離硫酸量が増大 して $\mathrm{pH}$ が低下し, $\mathrm{pH}$ の低下によって陰極への鉄析出 効率が低下するものと考えられる。 


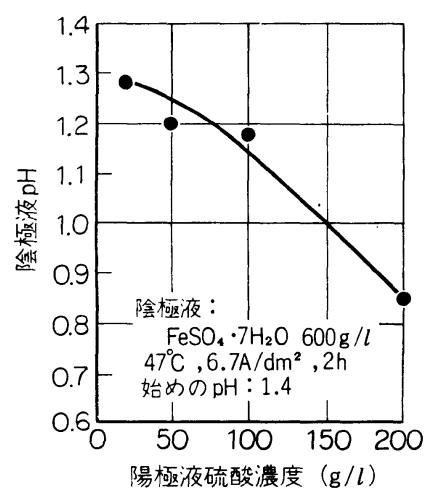

図 4 陽極液硫酸濃度之電解後の陰 極液 $\mathrm{pH}$ との関係

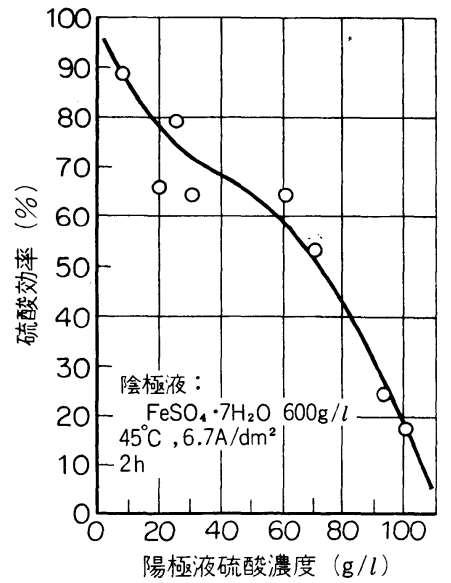

図 5 陽極硫酸濃度と硫酸生成効率の関係

した。電解時間はおのおの60 $\min$ である。図6(a)は, 陽極液 が硫酸溶液であり，(b)は(a)の各 濃度の硫酸溶液に水酸化アンモ ニウムを少量ずつ添加して徐々 に中和していった場合, 添加し た水酸化アンモニウムと化学的 当量よりも余剰である硫酸濃度 と硫酸効率の関係を示したもの である。陽極液が硫酸のみの場 合, 硫酸濃度が $5 \mathrm{~g} / l$ のとさに 硫酸生成効率は $88 \%, 10 \mathrm{~g} / \mathrm{l}$ の ときに約 $80 \%, 15 \mathrm{~g} / l$ のときに

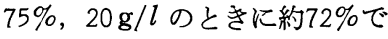

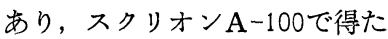

\section{3一3 硫酸生成効率におよぼす陽極液硫酸濃度の影響}

陽極液硫酸濃度を高くしていった場合に陰極室硫酸第 一鉄水溶液から陽極液へ電解透析する硫酸効率すなわち 陽極室での硫酸生成電流効率は大きく変化すると考えら れる。これらの関係についての実験結果を図 5 に示し た。使用した陰イオン交換膜はスクリオンA-100であ る。硫酸量の測定は水酸化ナトリウムによる滴定法によ り, 硫酸生成効率は電解電流効率で示した。

図から明らかなように, 硫酸生成効率に対する陽極液 硫酸濃度の影響は大きい。測定值のバラッキがやや大き いが，陽極液硫酸濃度が $10 \mathrm{~g} / l$ の時硫酸生成効率は約 88 $\%, 20 \mathrm{~g} / l$ のとき約 $80 \%, 50 \mathrm{~g} / l$ のとき60～65\%となる。 陽極液硫酸濃度が $100 \mathrm{~g} / l$ と高くなると, 硫酸効率は約 $20 \%$ 程度に低下してしまう。陽極液硫酸濃度と硫酸透析 効率との関係は, 硫酸ナトリウム溶液について織田ら ${ }^{12)}$ が得た効率よりも，硫酸濃度 $50 \mathrm{~g} / l$ 以下の低濃度におい て約 $10 \%$ 低い值である。

つぎに，陰イオン交換膜としてネオセプターAF-4T を用い, 陽極液硫酸濃度 $30 \mathrm{~g} / l$ 以下の低濃度について陽 極室への硫酸透析効率 (生成効率) との関係を図 6 に示

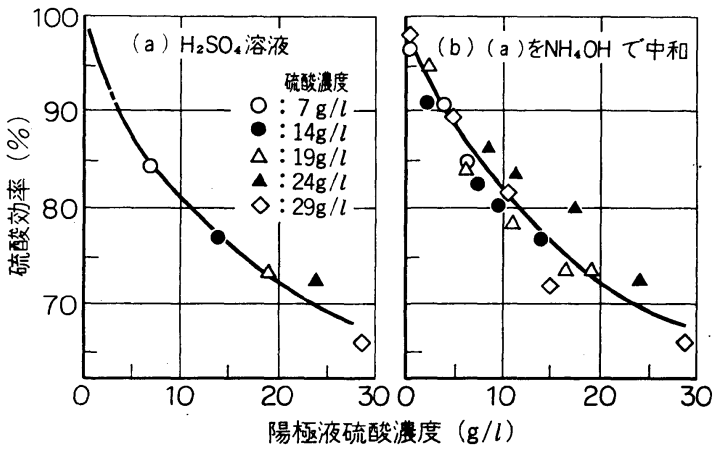

図 6 陽極液硫酸濃度之硫酸生成効率の関係
結果よりも数\%低い值である。硫酸溶液に水酸化アンモ ニウムを加えていった場合, 残留している硫酸量と硫酸 生成効率の関係は, 水酸化アンモニウムを加えない硫酸 単独の曲線とよく一致している。このことは陽極液中に 硫酸アンモニウム塩が存在しても硫酸効率への影響は小 さく, 陽極液中の遊離の硫酸量によって硫酸効率が決ま ることを示すものである。硫酸生成効率をできるだけ高 くするために, 陽極液中の硫酸濃度を低くしていくと, 液抵抗のために電解電圧が上昇し, 電解電力の増大をき たすが，電解電生を低く保ち，かつ硫酸生成効率を高く 保つためには，水酸化アンモニウムや，水酸化ナトリウ ム，あるいは水酸化カルシウムやこれらの炭酸塩などを 用いて，陽極液中の硫酸濃度を低く拈さえ，かつ液の電 導度を高くすることが有効であるといえる。

図 7 は陽極液硫酸濃度が $7 \mathrm{~g} / l, 14,19,24,29 \mathrm{~g} / l$ の溶液に水酸化アンモニウムを添加していった場合の陽 極液 $\mathrm{pH}$ と陽極室での硫酸生成効率の関係を示しための

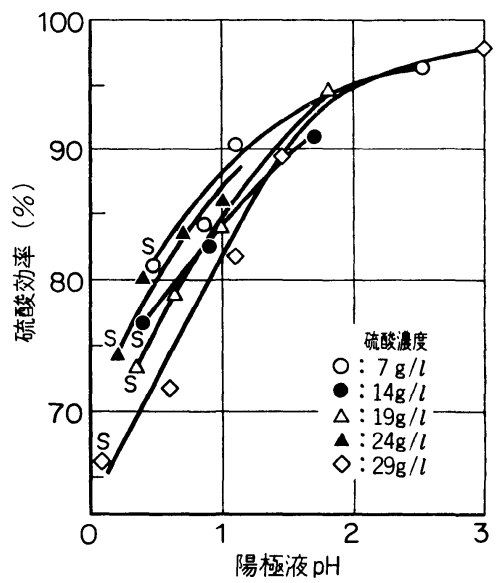

図 7 陽極液 $\mathrm{pH}$ と硫酸生成効率の関係 


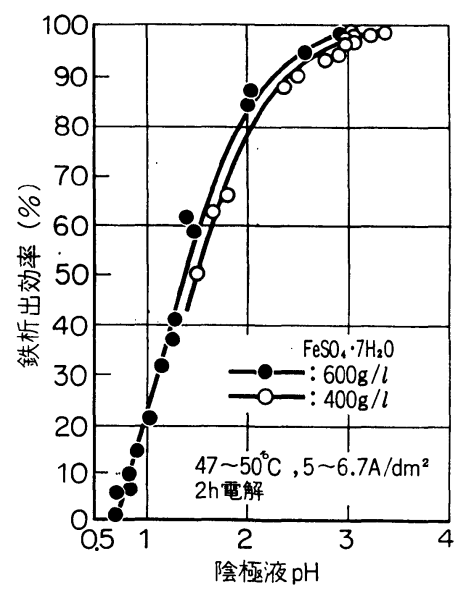

図 8 陰極液 $\mathrm{pH}$ と鉄析出効率の関係

である。図 6 と同様，陰極液は硫酸第一鉄 7 水塩 $350 \mathrm{~g} / l$ に硫酸アンモニウム $100 \mathrm{~g} / l$ を添加した溶液で, 陰極液 $\mathrm{pH} 5.0$, 電流密度 $3 \mathrm{~A} / \mathrm{dm}^{2}$, ネオセプタ一使用, 電解60 min である。陽極液 $\mathrm{pH}$ が 1 のとき硫酸生成効率は約 80 〜90\%, 陽極液 $\mathrm{pH}$ が1.5では硫酸生成効率は90〜93\%, $\mathrm{pH} 2$ では 95\% と高い硫酸生成効率を保つことができる ことがわかる。

以上に記したように，不溶性陽極を用い，陰イオン交 換膜を使用した 2 室電解において，陰極液硫酸第一鉄水 溶液中の硫酸根を, 硫酸として高い濃度で陽極室に生成 させることは, 硫酸生成効率が著しく低下するために困 難であり, この点を考慮して, 陽極室に生成させる硫酸 濃度は50 60 g/l が上限と考兄られ, 硫酸生成効率を高 く維持するためには，陽極液硫酸濃度はできるだけ低く 保つことが必要であり, 水酸化アンモニウムやアルカリ を添加して電導度を保ち, 硫酸濃度を $\mathrm{pH}$ で 0.5〜 3 程 度に保つことは, 陽極に生成する硫酸効率をきわめて高 く保つために有効であるといえる。

陽極室に生成する 硫酸濃度を50～60 g/l 以上に高く し, かつ硫酸の生成効率をより高く保つために, 陽極室 と陰極室の間に, さらに第 3 の中間室を設け, 中間室に 低濃度の硫酸水溶液を用い, 陽極室飞高濃度の硫酸を生 成させる 3 室電解法が有利であることが明らかとなった が13)，この結果については省略する。

\section{3-4 鉄析出効率におよぼす陰極液 pH の影䉕}

陰極室硫酸第一鉄水溶液 $\mathrm{pH}$ と鉄析出効率の関係につ いて， $\mathrm{pH}$ を0.6から3.4と变化させた場合の結果を図 8 に示した。

図 8からわかるように, 陰極液の $\mathrm{pH}$ は鉄析出効率を 左右する最大の要因であり, $\mathrm{pH}$ が 0.6 程度では鉄析出 効率はほぼゼロである。 $\mathrm{pH}$ が 2〜2.5以下の範囲では, $\mathrm{pH}$ の変化に対する鉄析出効率の変化は大きく, $\mathrm{pH}$ の

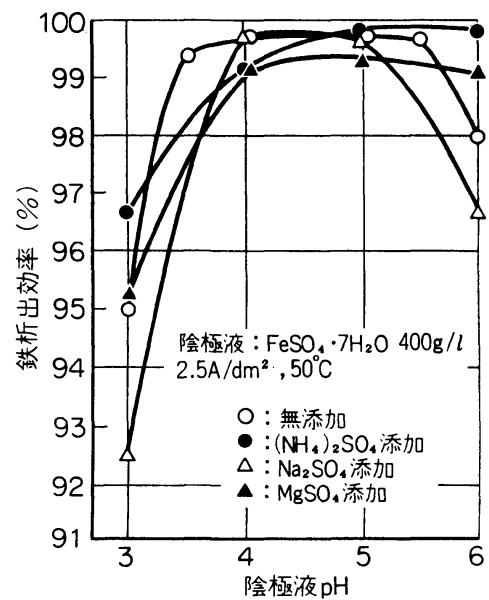

図 9 鉄析出効率之陰極液 $\mathrm{pH}$ の関係

低下とともに鉄析出効率は急激に低下する。陰極液 $\mathrm{pH}$ が2.5の場合, 鉄析出効率は 90〜94\%, pH を3.0以上とす れば鉄析出効率を95〜99\%とすることができる。 $\mathrm{pH} 3.0$ 以下に括いては，硫酸第一鉄濃度が $400 \mathrm{~g} / \mathrm{l}$ よりも600g/ $l$ と高いほうが鉄析出効率が高い。

硫酸第一鉄の単純浴拉よび硫酸アンモニウム, 硫酸ナ トリウム拉よび硫酸マグネシウムをそれぞれ別個に 100 $\mathrm{g} / l$ 添加した浴について, 陰極液 $\mathrm{pH}$ を3.0から6.0の範 囲で变化させた場合の鉄析出効率との関係を図 9に示し た。

陰極液. $\mathrm{pH}$ が 3.0の場合, 鉄析出効率は 92.5 から 96.7 の間にあり, 硫酸ナトリウム添加浴が低く, 硫酸アンモ ニウム添加浴が高い効率を示す。 $\mathrm{pH}$ を4.0にあげると， 鉄析出効率はすべて $99 \%$ 以上となり $\mathrm{pH} 5.0$ の場合る同 じである。 $\mathrm{pH}$ を6.0 とすると硫酸ナトリウム添加浴で $96.6 \%$, 単純浴で $98 \%$ に低下し, 硫酸マグネシウム添加 浴でも若干低下傾向を示し, 硫酸アンモニウム添加浴で は効率は低下しない。

硫酸第一鉄水溶液に添加する塩の種類によって, $\mathrm{pH}$ の変化に対する鉄析出効率の変化に差があるといらこと がいえる。

\section{4. 考察}

陰イオン交換膜を使用した 2 室電解において, 陰極液 $\mathrm{pH}$ と陽極液硫酸濃度が鉄析出効率拐よび 硫酸生成効率 にきわめて大きい影響を㧊よぼすことがわかった。

陰イオン交換膜は理想的には陰極液中の陰イオンであ る硫酸根のみを陽極液中に透過せしめ, 陽イオンに対し ては完全に阻止効果を持つべきであるが，陽極室硫酸濃 度が高くなるにつれて陰イオン交换膜中の硫酸根の輸率 は低下し，代わりに陽極液中に增大した水素イオンの輸 率が大となり, 陽極液中の水素イオンが陰イオン交換膜 
を通して陰極液中に透析してくる。この結果, 陰極液の $\mathrm{pH}$ は低下乙鉄析出効率は低下する。また, 陰イオン交 換膜の特性として，電場を与えなくても膜をはさんで接 する両側の溶液の濃度差による払散透析が起こるため, 陽極液硫酸濃度が高いと濃度差による駆動力のために電 解準備中や電解中の微少電流に抗して陽極液から陰極液 への硫酸の透析が起こりらるものと考えられる。

図 2 に示すよらに，電解時間の経過とともに陰極液 $\mathrm{pH}$ が低下し, 鉄析出効率も低下してくることは, 陽極室 に透析する硫酸効率が鉄析出効率を下回わることに起因 し, 乙かも電解継続とともに陽極液硫酸濃度はしたいに 増大し, この結果, 硫酸透析効率は低下し, 陽極室から 陰極室へ透析する水素イオン量が増大し, 陰極液 $\mathrm{pH}$ の 低下と鉄析出効率の低下が進む。これらの低下の度合い は電解電流に対する陰極液量および陽極液量によって変 化し，液量が少ないほど低下が大きいことはいうまでも ない。電解時間の経過にともなら鉄析出効率および硫酸 生成効率を高い值で一定に保つためには，陰極液 $\mathrm{pH}$ お よび陽極液硫酸濃度を所定の值に常に一定に保持するこ とが必要であり，鉄析出効率と硫酸生成効率が同一の場 合には電解系は均衡を保つが，これらが同一でない場合 にはこの差をなくす方向に電解系は移動する。

\section{5. 結 論}

不溶性陽極を用い，陰イオン交換膜を使用した 2 室電 解槽で陰極室に硫酸第一鉄水溶液を主液とし陽極室に硫 酸を生成させる電解において, 陽極液硫酸濃度と陰極液 $\mathrm{pH}$ の間には密接な関係があり，これらは陽極室での硫 酸生成効率および陰極での鉄析出効率に大きな影響を拉 よぼすことがわかった。

電解時間の経過とともに陽極液硫酸濃度が増大し, 陰 極液 $\mathrm{pH}$ は低下し鉄析出効率が低下寸る。

陰極液 $\mathrm{pH}$ は陽極液硫酸濃度が高いほど電解中に低下 する。

陽極室に打ける硫酸生成効率は陽極液硫酸濃度が低い ほど高く，濃度 $5 \mathrm{~g} / l$ で約8 $8 \% ， 50 \mathrm{~g} / l$ で約 $65 \%$ の効率 である。陽極液に水酸化アンモニウムなどを加えて可溶 性塩を作り $\mathrm{pH}$ を0.5〜3に保てば，硫酸生成効率は約 $75 \%$ 以上 $96 \%$ と高くすることができる。
鉄析出効率は陰極液 $\mathrm{pH}$ に大きな影響をうけ, 陰極液 $\mathrm{pH} 2.5$ で 90〜 94\%, $\mathrm{pH} 3.0$ 以上で 95\% 99\%の効率と

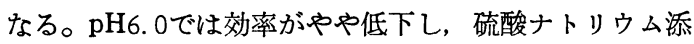
加浴で低下が大きいが，硫酸アンモニウム添加浴では効 率の低下はない。効率の点から好ましい範囲は $\mathrm{pH} 2.5 \sim$ 6である。

陰極液 $\mathrm{pH}$ が比較的低い場合, 硫酸第一鉄濃度が高い ほらが同一 $\mathrm{pH}$ に対して鉄析出効率は高くなる。

電解時間の経過にともなう鉄析出効率扣よび硫酸生成 効率を一定に保つためには, 陰極液 $\mathrm{pH}$ 执よび陽極液硫 酸濃度を所定の值に常に一定に保つことが必要であり, 鉄および硫酸の効率を高く保つためには, 陽極液硫酸濃 度を約 50〜 60g/l 以下, 陰極液 $\mathrm{pH}$ を約 2.5 以上に高く 保つことが必要である。

(1973-7-26 受理)

(昭和42年10月, 化学関係学協会連合大会际よび昭和 47 年11月, 本協会第46回学術講演大会にて一部発表）

\section{文献}

1) D. Belcher, Trans. Am. Electrochem. Soc., 45, 455 (1924)

2) Cunningham, U.S. P., 2852452, Sept., (1958)

3) 清山哲郎, 電気化学, 33, 527 (1965)

4) 尾上康治, 電気化学, 33, 530 (1965)

5) 小坂勇次郎, 清水 博, イオン交換膜 (1963, 共立 出版社)

6) 山辺武郎, 妹尾 学, イオン交換樹脂膜 (1964, 技 報堂)

7) F. Helfferich, Ion Exchange (1962, Mc Graw Hill)

8) 永松政俊, 清山哲郎, 坂井 渡, 電気化学, 24,79 (1956)

9) 石橋信彦, 清山哲郎, 坂井 渡, 電気化学, 24,321 (1956)

10) C. Horner et al, Indust. Eng Chem. 47, 1121 (1955)

11) G. W. Bodamer et al., U.S.P., 2810686, Oct., (1957)

12）織田健一, 富沢 利, 斎藤武男, 電気化学, 29,154 (1961)

13）近藤嘉一，福永博之，特公昭46-21089（1971） 